\title{
Partycypacja mniejszości niemieckiej w polskim życiu publicznym po 1989 r. - przypadek Ślq̨ska Opolskiego
}

\section{MAREK MAZURKIEWICZ}

Państwowy Instytut Naukowy - Instytut Śląski w Opolu

\section{ROCZNIK}

\section{ZIEM}

\section{ZACHODNICH}

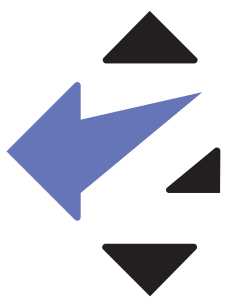




\section{Wstęp}

Upadek komunizmu w Polsce odsłonił skrywane i przez dziesięciolecia przemilczane fakty dotyczące obecności w kraju mniejszości narodowych i etnicznych. Uświadomienie sobie, że Polska jest krajem wielokulturowym i wielonarodowym mogło być w okresie przełomu demokratycznego dla wielu środowisk społecznych i politycznych sporym zaskoczeniem. Upadły bowiem wówczas głoszone i przez lata starannie pielęgnowane poglądy o tym, że zastosowane w drugiej połowie lat 40 . ubiegłego stulecia narzędzia polityki narodowościowej, na czele z masową wymianą ludności, pozwoliły na stworzenie jednego z najbardziej monoetnicznych społeczeństw w Europie.

Głoszenie poglądów o jednolitym pod względem narodowościowym składzie powojennego polskiego społeczeństwa łączyło się bowiem z myślą przewodnią popularnej po II wojnie światowej doktryny państw narodowych. Warto pamiętać, że tę wówczas żywotną i w wielu krajach Europy Środkowej i Wschodniej obowiązującą doktrynę uważano za jedną z najlepszych form zabezpieczenia przed niepokojami społecznymi i rodzącymi się na ich gruncie konfliktami zbrojnymi. Aczkolwiek w żadnym ze znanych przypadków jej wdrażanie nie zakończyło się pełnym powodzeniem - a w praktyce - jedynie ujednoliceniem pod względem etnicznym wspólnoty narodowej. W krajach, gdzie dokonano pod tym względem największych zmian po II wojnie światowej, czyli w Polsce i Czechosłowacji, po 1950 r. nadal zamieszkiwali przedstawiciele mniejszości narodowych i etnicznych, choć częstokroć w bardzo osłabionych liczebnie i tożsamościowo społecznościach ${ }^{1}$. Państwa te realizowały wobec tych grup politykę przymusowej asymilacji, obarczonej dodatkowo ideologiczną nadbudową. Szczególnie było to widoczne na przykładzie polityki względem niemieckiej grupy narodowościowej.

W rezultacie w powojennej Europie, a zwłaszcza w Polsce, starano się za wszelką cenę udowodnić fakt, że wraz z zakończeniem procesu budowania powojennego ładu na Kontynencie (w latach 1945-1950) rozwiązano kwestię obecności „problematycznych" mniejszości narodowych i etnicznych ${ }^{2}$. Bagatelizowano przy tym znaczenie procesów zmian tożsamościowych, jakie w sposób pośredni zostały uruchomione poprzez wdrożone wtedy narzędzia polityki narodowościowej. Narzędzia te

1 Zarówno zawarcie układu monachijskiego z 1938 r., które przyczyniło się do terytorialnego demontażu Czechosłowacji, jak i katastrofa II wojny światowej posłużyły do ugruntowania wśród społeczności międzynarodowej przekonania o konieczności stosowania radykalnych rozwiązań z dziedziny polityki narodowościowej. Trafnie ten punkt widzenia obrazuje fragment opracowania popularnonaukowego Krzysztofa Skubiszewskiego z 1968 r., który w kilku zdaniach ujałł myśl przewodnia zasadności przeprowadzenia powojennych masowych przesunięć ludnościowych: „Wroga wobec państwa-gospodarza działalność mniejszości niemieckiej zwróciła uwagę państw europejskich na to, że w pewnych sytuacjach mniejszość staje się narzędziem polityki groźnej dla pokoju i źródłem konfliktów międzynarodowych. Dlatego też jako rozwiązanie alternatywne - w stosunku do międzynarodowej ochrony mniejszości - rodzi się koncepcja przesiedlenia kłopotliwej mniejszości, zwłaszcza gdy nie chce ona zająć postawy lojalnej wobec państwa, na którego obszarze zamieszkuje”. Cyt. za: K. Skubiszewski, Wysiedlenie Niemców po II wojnie światowej, Warszawa 1968, s. 14-15.

2 Według ówczesnego przekonania, lata 30. ubiegłego stulecia były tym okresem, który udowodnił, że „[...] specjalna pozycja grupy mniejszościowej w obrębie danego państwa mogła stać się w ręku zaborczego i pozbawionego skrupułów rządu innego państwa narzędziem polityki zmierzającej do rozszerzania sfery jego wpływów, a następnie prowadzącej do rewizji granic i zaborów”. Cyt. za: ibidem, s. 11. 
spaczone „czarno-białym” postrzeganiem rzeczywistości narodowościowo-etnicznej przynosiły w niektórych przypadkach odwrotne od zamierzonych skutki. I tak, polskie władze komunistyczne nie starały się zrozumieć faktu, że na terenie PRL, przez cały okres jej istnienia, zamieszkiwało ponad dziesięć różnych grup narodowościowych i etnicznych.

Ich obecność została potwierdzona jednak dopiero po ogłoszeniu wyników Spisu Powszechnego z 2002 r., a pełne ich uznanie w wymiarze prawnym nastąpiło w 2005 r., kiedy 6 stycznia tego roku Sejm RP V kadencji uchwalił ustawę o mniejszościach narodowych i etnicznych i o języku regionalnym ${ }^{3}$, uznając obecność dziewięciu mniejszości narodowych i czterech mniejszości etnicznych ${ }^{4}$. Spośród nich najbardziej liczebną była i jest do dzisiaj mniejszość niemiecka, skupiona głównie na terenie Śląska Opolskiego.

Budowa polskiego systemu wsparcia mniejszości narodowych i etnicznych trwała prawie 16 lat. Nie oznacza to jednak, że dopiero w 2005 r. mniejszości uzyskały pełną podmiotowość i zarazem możliwość całkowitej partycypacji w życiu społeczno-politycznym RP. Przez okres lat 1989-2005 budowały bowiem bagaż doświadczeń i swoją aktywnością udowadniały, że mit polskiego społeczeństwa jednolitego pod względem narodowościowym był jednym z wielu kłamstw, które legły u podstaw tworzenia komunistycznego państwa po II wojnie światowej ${ }^{5}$.

Być może najistotniejszą rolę $\mathrm{w}$ tym względzie odegrała właśnie mniejszość niemiecka na Śląsku Opolskim, która swoją wszechstronną aktywnością w jego życiu społeczno-kulturalnym z jednej strony przyczyniała się do budowy społeczeństwa obywatelskiego regionu, z drugiej zaś współkształtowała jego życie polityczne. Przykład mniejszości niemieckiej wydaje się interesujący pod względem badawczym pod wieloma względami. Daje on bowiem możliwość wielopłaszczyznowej analizy funkcjonowania samej społeczności polskich Niemców oraz pozwala spojrzeć na ewolucję postrzegania mniejszości narodowych i etnicznych przez społeczeństwo większościowe, a także prześledzenia procesu budowy państwowego systemu wsparcia skierowanego na rzecz wszystkich takich społeczności w Polsce.

Przybliżenie przykładów działalności i osiągnięć mniejszości niemieckiej w obszarze politycznym, a także w zakresie wykorzystywania możliwości polskiego systemu

3 Ustawa z dnia 6 I 2005 r. o mniejszościach narodowych i etnicznych oraz o języku regionalnym dostepna na stronach Internetowego Systemu Aktów Prawnych: http://isap.sejm.gov.pl/DetailsServlet?id=WDU20050170141 (dostęp: 10 IX 2016 r.)

4 Uznanymi w Polsce mniejszościami narodowymi są: mniejszość litewska, białoruska, ukraińska słowacka, czeska, niemiecka, rosyjska, żydowska, ormiańska, a mniejszościami etnicznymi są: mniejszość romska, łemkowska, tatarska i karaimska.

5 Warto pamiętać, że już Konstytucja RP z 2 IV 1997 r., w art. 35 stworzyła katalog wolności mniejszości narodowych i etnicznych: „1. Rzeczpospolita Polska zapewnia obywatelom polskim należącym do mniejszości narodowych i etnicznych wolność zachowania i rozwoju własnego języka, zachowania obyczajów i tradycji oraz rozwoju własnej kultury. 2. Mniejszości narodowe i etniczne mają prawo do tworzenia własnych instytucji edukacyjnych, kulturalnych i instytucji służących ochronie tożsamości religijnej oraz do uczestnictwa w rozstrzyganiu spraw dotyczących ich tożsamości kulturowej". Tekst Konstytucji dostępny m.in. na stronie internetowej Sejmu RP: http://www.sejm.gov.pl/prawo/konst/polski/kon1.htm (dostęp: 10 IX 2016 r.) 
wsparcia na rzecz mniejszości narodowych i etnicznych, pozwoli na systemowe przedstawienie aktywności tej społeczności w polskim życiu publicznym po $1989 \mathrm{r}$. Istotne w tym względzie będzie też przybliżenie cyklu wydarzeń z okresu 1989/1990, których splot umożliwił powstanie ruchu mniejszości niemieckiej, a pośrednio ukierunkował ich główne obszary działalności, spośród których wymiar polityczny zajmuje do dzisiaj czołową pozycję.

Ambicją artykułu jest zatem syntetyczne naświetlenie obecności mniejszości niemieckiej w życiu społeczno-politycznym Śląska Opolskiego. Obecność tę autor określa terminem partycypacji, przez którą rozumie przede wszystkim działalność organizacji mniejszości niemieckiej oraz udział w wyborach powszechnych komitetów wyborczych tworzonych przez te podmioty. Śląsk Opolski rozumiany jest przy tym jako część historycznego obszaru Górnego Śląska, ograniczony do administracyjnego terenu województwa opolskiego. Przyjęcie politologicznej optyki badawczej powoduje, że zagadnienie partycypacji mniejszości niemieckiej w życiu publicznym prezentowane jest głównie z punktu widzenia instytucjonalnego. Autor w analizie pomija kwestie wpływu zjawiska tożsamościowej emancypacji części ludności rodzimej Śląska (śląskość rozumiana jako odrębna postawa tożsamościowa w wymiarze narodowościowym lub etnicznym) na ruch mniejszości niemieckiej, ponieważ zagadnienie to wymaga odrębnego omówienia i przekroczyłoby ramy niniejszego artykułu.

\section{Odrodzenie mniejszości niemieckiej}

Znaczącym wydarzeniem, które w wymiarze krajowym, a także bilateralnym można uznać za odrodzenie mniejszości niemieckiej w Polsce, była słynna „Msza Pojednania", czyli nabożeństwo ekumeniczne, które odbyło się w dolnośląskiej Krzyżowej 12 listopada 1989 r. Nabożeństwo przeszło do historii polsko-niemieckiego sąsiedztwa poprzez niezwykle wymowny gest - przekazanie sobie znaku pokoju przez premiera Tadeusza Mazowieckiego i kanclerza Helmuta Kohla, a także przez fakt, że po raz pierwszy po 1950 r. w zgromadzeniu publicznym osoby narodowości niemieckiej zamieszkujące teren Polski mogły otwarcie zademonstrować swoją obecność ${ }^{6}$. Niektórzy z nich trzymali transparenty z napisem dedykowanym kanclerzowi Republiki Federalnej Niemiec: „Helmut, jesteś także naszym kanclerzem”

6 Licznie reprezentowani podczas nabożeństwa przedstawiciele mniejszości niemieckiej zostali także przywitani przez duchownych. W słowach powitania, wygłoszonych przez bp. Tadeusza Rybaka, zostali oni nazwani „przedstawicielami Narodu Niemieckiego”, którzy na stałe zamieszkują Polskę: „Serdecznie witam Prezesa Rady Ministrów Pana Tadeusza Mazowieckiego, o którym mówimy «nasz Premier», bo cieszy się zaufaniem społeczeństwa polskiego i prowadzi kraj do tych wartości, o jakie naród nasz walczył przez długie lata, i jakimi pragnie żyć. Witam wszystkich obecnych członków Rządu Polskiego i towarzyszące Panu Premierowi osoby. [...] Jest dla nas szczególną radością, że w zgromadzonej tu chrześcijańskiej wspólnocie możemy dziś z wielkim szacunkiem powitać Pana Kanclerza Federalnego Helmuta Kohla i wszystkich przedstawicieli Narodu Niemieckiego, którzy razem z Panem Kanclerzem przybyli tu z Republiki Federalnej Niemiec i którzy stale mieszkaja na terenie Polski [podkr. aut.] [...]. Całym sercem witam i pozdrawiam Was, Drodzy Rodacy i dziękuję, że przybyliście tak licznie, by dać wyraz naszej polskiej solidarności w wierze i w nadziei, która zwieść nie może”. Opracowanie nt. Mszy Pojednania dostępne na stronie internetowej http://www.mszapojednania.pl/index.php?option=com_content\&view=article\&id=7\&lang=pl (dostęp: 10 VIII 2016 r.), utworzonej z okazji jubileuszu 25-lecia wydarzenia. 
(niem. Helmut du bist auch unser Kanzler) $)^{7}$. Jest to być może - obok wspomnianego gestu szefów rządu polskiego i zachodnioniemieckiego - najbardziej zapamiętany obraz z tamtego wydarzenia, który w wymiarze medialnym zrodził wiele, podszytych stereotypami, obaw co do przyszłego rozwoju wydarzeń na arenie międzynarodowej, którego skutki promieniowały także na Śląsk Opolski.

To aktywne zaznaczanie swojej obecności było najbardziej widocznym, ale jednym z wielu przejawów procesu odradzania się mniejszości niemieckiej. Emancypujący się wówczas przedstawiciele polskich Niemców niewątpliwie nabrali pewności siebie po tym, jak od czerwca 1989 r. mogli pierwszy raz od kilkudziesięciu lat uczestniczyć w nabożeństwach odprawianych w języku niemieckim.

4 czerwca tego roku, czyli w dniu wyborów do Sejmu Kontraktowego, w wyniku których system komunistyczny został w Polsce w sposób ewolucyjny zdemontowany, w sanktuarium na Górze Świętej Anny odbyła się Msza św. w języku niemieckim $^{8}$. Wkrótce język niemiecki zagościł w wielu innych parafiach Diecezji Opolskiej. Przyszłość pokazała jednak, że możliwość jego używania w nabożeństwach nie zaczęła promieniować na jego obecność w opolskim życiu publicznym. Trwająca kilkadziesiąt lat rozłąka z językiem niemieckim sprawiła, że do dziś nie zadomowił się on w opolskiej codzienności甲. Warto też pamiętać, że dla Ślązaków, niezależnie czy poczuwających się do tożsamości śląsko-niemieckiej, śląsko-polskiej czy też rozumiejących swoją śląskość w kategoriach odrębności etnicznej, to śląska gwara jest fundamentem ich samoidentyfikacji.

Zezwolenie na odprawianie nabożeństw w języku niemieckim („języku serca”) dla przedstawicieli odradzającej się mniejszości niemieckiej było także zwycięstwem w wymiarze symbolicznym. Zakończył się wtedy ponad 50-letni okres zakazu używania języka niemieckiego w przestrzeni publicznej na Górnym Śląsku, który wprowadzono wraz z instalacją polskich władz w tym regionie i rozpoczęciem powojennej przebudowy społeczeństwa. Dotąd bowiem język niemiecki był językiem „domowego zacisza” i osób najstarszego pokolenia. Wraz z jego odgórnym usunięciem z przestrzeni publicznej ci, którzy na Górnym Śląsku pozostali, ale czuli się mimo wszystko Niemcami, zyskali dodatkową trudność w przekazaniu elementów niemieckiej tożsamości młodszym pokoleniom.

Do połowy lat 80. XX w. polski dyskurs publiczny i polityczny nie był gotowy, aby podjąć temat obecności osób pochodzenia niemieckiego w PRL. Nie były do tego przygotowane również środowiska osób, które poczuwały się do związków z narodem niemieckim. Dopiero powolna erozja autorytarnego systemu rządów komunistycznych

7 Obszerniej zob.: R. Urban, Poczqtki zawsze sq trudne. Historia powstania TSKN na Ślqsku Opolskim, [w:] 20 lat TSKN na Ślqssku Opolskim, red. R. Urban, Z. Donath-Kasiura, Opole 2009, s. 17-18.

8 O dziejach Sanktuarium św. Anny na Górze św. Anny więcej zob.: http://www.swanna.com.pl/viewpage.php?page_id=6 (dostęp: 10 IX 2016 r.).

9 Problem ten opisuje autor na przykładzie możliwości używania języka niemieckiego jako języka pomocniczego w opolskich gminach wpisanych do Urzedowego Rejestru Gmin: M. Mazurkiewicz, Regionalne uwarunkowania polityki polskiej wobec mniejszości narodowych i etnicznych na przykładzie województwa opolskiego, „Studia Śląskie”, t. LXXVII (2016), s. 53-74. 
stworzyła szanse do podjęcia prób samoorganizacji. Od połowy lat 80. XX w. w wielu miastach województw, zarówno opolskiego, jak i katowickiego ${ }^{10}$, podejmowano szereg różnorodnych inicjatyw, których celem była legalizacja „Niemieckich Kół Przyjaźni" (niem. Deutscher Freundschaftskreis - DFK) lub niemieckich towarzystw społeczno-kulturalnych.

Michał Lis, powołując się na badania Zbigniewa Kurcza, wylicza, iż od 1984 do 1989 r. władze odmówiły legalizacji działalności organizacji zrzeszających ludność pochodzenia niemieckiego aż czternaście razy ${ }^{11}$. Odmowy rejestracji tych podmiotów władze argumentowały najczęściej stwierdzeniem, że w PRL nie było bazy ludnościowej, z której rekrutować mogli się ich działacze. Informacje o podejmowanych próbach rejestracji działalności podmiotów, zrzeszających polskich Niemców, nie przedostawały się do szerokiej publiczności. Należy mieć też świadomość, że sądy i właściwe organy administracji państwowej, odpowiedzialne za nadzór nad działalnością organizacji społecznych w PRL, odmawiając legalizacji towarzystw lub wspomnianych „kół przyjaźni”, nie chciały brać na siebie odpowiedzialności za wprowadzenie do polskiej rzeczywistości prawnej i społecznej precedensowych rozwiązań. Zmiany takiego podejścia stały się możliwe dopiero po rozpoczęciu procesu demokratyzacji.

Obrady „okrągłego stołu”, których rezultatem była zgoda na częściową demokratyzację wyborów i prawo uchwalone jeszcze przez Sejm PRL X kadencji, uruchomiły lawinę zmian ${ }^{12}$. Także dzięki nim w lutym 1990 r. przedstawicielom mniejszości niemieckiej udało się zalegalizować działalność Towarzystwa Społeczno-Kulturalnego Mniejszości Niemieckiej na Śląsku Opolskim (od 1993 r. Towarzystwa Społeczno-Kulturalnego Niemców na Śląsku Opolskim) ${ }^{13}$ (dalej: TSKN). Rok później udało się też utworzyć organizację dachową - Związek Niemieckich Stowarzyszeń Społeczno-Kulturalnych w Polsce, który stał się organizacją - patronem dla wszystkich podmiotów zrzeszających osoby narodowości niemieckiej lub działających na ich rzecz ${ }^{14}$.

10 Mowa o podziale administracyjnym Polski, który obowiązywał w latach 1975-1998. Spośród 49 istniejących wówczas regionów, województwo katowickie było największe pod względem liczby mieszkańców - przyp. aut.

11 M. Lis, Mniejszość niemiecka na Śląsku Opolskim 1989-2014. Z bagażem przeszłości w realiach współczesności, Opole 2015, s. 62-63.

127 IV 1989 r. uchwalono ustawę Prawo o stowarzyszeniach. Dokument ten zalicza się do nielicznych w polskim prawodawstwie ustaw, która ma preambułę. Mowa w niej jest, iż uchwalono ją: „W celu stworzenia warunków do pełnej realizacji gwarantowanej przepisami Konstytucji wolności zrzeszania się zgodnie z Powszechną Deklaracją Praw Człowieka i Międzynarodowym Paktem Praw Obywatelskich i Politycznych, umożliwienia obywatelom równego, bez wzgledu na przekonania, prawa czynnego uczestniczenia w życiu publicznym i wyrażania zróżnicowanych poglądów oraz realizacji indywidualnych zainteresowań, a także uwzględniając tradycje i powszechnie uznawany dorobek ruchu stowarzyszeniowego". Z punktu widzenia realnego wykorzystania wolności zrzeszania sie była to pierwsza po wojnie ustawa, która taką możliwość dawała. Była też jedną z pierwszych ustaw, które zbudowały demokratyczny system prawny i umożliwiły wprowadzenie pluralizmu w życiu publicznym. Tekst ustawy dostępny na stronach internetowych Internetowego Systemu Aktów Prawnych: http://isap.sejm.gov.pl/ DetailsServlet?id=WDU19890200104 (dostęp: 10 IX 2016 r.).

13 Więcej o organizacji zob.: http://skgd.pl/ (dostęp: 10 IX 2016 r.).

14 W dniach 3-4 IX 2016 r. odbyły się obchody 25-lecia funkcjonowania Związku (Verband der deutschen sozial-kulturellen Gesellschaften in Polen), relacje prasowe oraz informacje nt. organizacji zob.: http://vdg.pl/pl/article/3772-4-wrzesnia-dzien-otwartych-drzwi-w-opolu (dostęp: 10 IX 2016 r.). 
Nim to jednak nastąpiło, nabierające pewności siebie środowisko mniejszości niemieckiej zaliczyło kolejne porażki. Co prawda w coraz większej liczbie kościołów na terenie diecezji opolskiej można było już usłyszeć język niemiecki, nie miał on jednak wpływu na stosunek władz publicznych do tolerowania działalności podmiotów zrzeszających obywateli PRL, deklarujących inne niż polskie pochodzenie etniczne.

W lipcu 1989 r. Sąd Wojewódzki w Opolu odmówił rejestracji Towarzystwu Społeczno-Kulturalnemu Mniejszości Niemieckiej ${ }^{15}$. Warto przypomnieć, że staraniom legalizacji działalności organizacji mniejszości niemieckiej towarzyszyła akcja zbierania podpisów pod deklaracjami woli wstępowania w szeregi organizacji mniejszości niemieckiej. Celem akcji - wcale nie kontrowersyjnej ${ }^{16}$ - było z jednej strony pokazanie liczebności społeczności, która otwarcie deklaruje tożsamościowe związki z narodem niemieckim, z drugiej zaś - wywarcie presji na polskich władzach i tym sposobem wymuszenie na nich zgody na rejestrację.

Nie można również zapominać, że proces odradzania się mniejszości niemieckiej, w sensie jej społecznej, kulturalnej, a później także politycznej emancypacji, realizował się w dynamicznym okresie zmian na arenie międzynarodowej. Szczególne znaczenie zyskał naturalnie $\mathrm{w}$ wymiarze polsko-niemieckim, gdyż proces demokratyzacji polskiego systemu politycznego równał się z koniecznością reorientacji kierunków i priorytetów polityki zagranicznej. W praktyce oznaczało to, że pojawiła się szansa na podjęcie próby ukształtowania polsko-niemieckich relacji w oparciu o czynniki niezależne od uwarunkowań ideologicznych i geostrategicznych.

Elementów, które wskazywały na zasadność budowy podstaw do rozwoju dobrosąsiedzkich relacji było wiele, spośród nich najistotniejszą rolę odgrywały względy ekonomiczne. Perspektywiczna pomoc finansowa i gospodarcza Republiki Federalnej Niemiec dla znajdującej się w opłakanym stanie polskiej gospodarki z jednej strony dawała nadzieję na poprawę sytuacji ekonomicznej Polski, z drugiej jednak osłabiała pozycję kraju w kontekście przyszłych negocjacji na płaszczyźnie bilateralnej ${ }^{17}$. W tej sytuacji rząd (wciąż jeszcze) Niemiec Zachodnich miał sporo atutów, które zostały następnie wykorzystane przy przeforsowywaniu własnych interesów. Od lat bowiem kwestie społeczne należały do problematycznych i trudnych do rozwiązania zagadnień wzajemnych relacji ${ }^{18}$. Dlatego sprawa odradzania się mniejszości niemieckiej oraz legalizacji działalności ich organizacji szybko stała się przedmiotem polsko-niemieckich rozmów na poziomie politycznym. Można zadać sobie pytanie, jak dalece istotne okazało się to już po wspomnianej wizycie H. Kohla.

15 M. Lis, Mniejszość niemiecka..., s. 65. Por. także: M. Cygański, Polityka Republiki Federalnej Niemiec wobec polskiej ludności rodzimej na Ślqsku w latach 1949-1990/91, Opole 1991, s. 46-47.

16 Rzadko wspomina się dziś, że w wielu rejonach województwa opolskiego aktywiści mniejszości niemieckiej, którzy zbierali podpisy poparcia, stosowali zachęty w postaci gratyfikacji pieniężnej - przyp aut.

17 J. Sawczuk, Od status quo do planu Kohla. Geneza zjednoczenia Niemiec w świetle opublikowanych dokumentów Urzędu Kanclerskiego (1989 r.), Opole 2005, s. 114.

18 K. Tokarz, Mniejszość niemiecka $w$ Polsce w prasie RFN w latach 1989-1997, [w:] Węzłowe problemy Niemiec XX-XXI wieku, red. K. Fiedor, M.S. Wolański, Wrocław 2002, s. 155-156. 
W wydanym tuż po wizycie Wspólnym Oświadczeniu znalazły się zagadnienia, które dla rządu federalnego, w kontekście przyszłych negocjacji poprzedzających zawarcie traktatu granicznego z 14 października 1990 r. i dobrosąsiedzkiego z 17 czerwca 1991 r., miały priorytetowe znaczenie. Zaliczały się do nich kwestie: opracowania i uchwalenia katalogu praw na rzecz mniejszości niemieckiej w Polsce, wznowienie możliwości nauki języka niemieckiego dla dzieci i młodzieży, tożsamościowo związanych z narodem niemieckim, a także opieki nad grobami wojennymi żołnierzy niemieckich, którzy polegli na terenie Polski ${ }^{19}$.

Katalog ten starały się poszerzyć organizacje niemieckich wysiedlonych, które nie tylko chciały włączyć się w proces polsko-niemieckiego dialogu, lecz także dążyły do poszerzenia agendy rozmów o ich interesy ${ }^{20}$.

Rząd Mazowieckiego, rozpoczynając proces polsko-niemieckiego zbliżenia i ostatecznej normalizacji wzajemnych stosunków, musiał zatem brać pod uwagę presję związaną z dążeniami mniejszości niemieckiej, która chciała uzyskać zgodę na legalizację ich działalności, dodatkowo wspieraną nie tylko przez rząd federalny, lecz także medialnie aktywne, a przez to kontrowersyjne w odbiorze organizacje wysiedlonych. Sytuacja ta była dodatkowo komplikowana przez rozpoczęty równolegle proces zjednoczenia Niemiec. W tym kontekście na czoło wysunęła się kwestia ostatecznego potwierdzenia polsko-niemieckiej granicy na Odrze i Nysie Łużyckiej.

Różnice w interpretacji ustaleń i skutków prawnomiędzynarodowej formy zakończenia II wojny światowej w odniesieniu do Polski i Niemiec były bowiem zasadniczymi problemami nie tylko stosunków na linii Warszawa-Bonn, lecz także na płaszczyźnie relacji Wschód-Zachód ${ }^{21}$. W odbiorze medialnym wzrastająca aktywność mniejszości niemieckiej w Polsce, jak również dochodzące zza zachodniej granicy głosy o konieczności nowej regulacji polsko-niemieckiej granicy, a ponadto dynamizm zmian na arenie międzynarodowej - budowały emocjonalny i trudny do przewidzenia kontekst przyszłego obrazu Europy.

W polskim odbiorze wcale nierzadkie były głosy wskazujące na zagrożenie związane z potencjalną rewizją kształtu polsko-niemieckiej granicy. Odradzającej się mniejszości niemieckiej nadawano, w tym kontekście, negatywną rolę. Emocjonalny ton przejmowały również niektóre opracowania naukowe. Za przykład podać tu można narrację cytowanego wyżej artykułu Mirosława Cygańskiego, która pod tym

19 Spośród polskich zobowiązań zawartych we Wspólnym Oświadczeniu można wymienić: „Polska Rzeczpospolita Ludowa i Republika Federalna Niemiec, pamiętając o tragicznych i bolesnych kartach historii, są zdecydowane kształtować swoje stosunki z myślą o przyszłości i tym samym dawać przykład dobrego sąsiedztwa. [...] Zapoczątkowane w Polskiej Rzeczypospolitej Ludowej daleko idące reformy w sferze politycznej, gospodarczej i społecznej oraz otwarcie wobec Europy i świata znacznie zwiększaja możliwości współpracy i pojednania obu narodów”. Cyt. za: 14 listopada 1989, wspólne oświadczenie Mazowiecki-Kohl, [w:] Polska-Niemcy 1945-2007. Od konfrontacji do współpracy i partnerstwa w Europie. Studia i dokumenty, red. W.M. Góralski, Warszawa 2007, s. 355.

20 Problem szczegółowo omówiono w rozdziale V książki autora, zob. M. Mazurkiewicz, Spór o pamięć Polityczne nastepstwa powojennych wysiedleń Niemców w pozimnowojennych relacjach polsko-niemieckich i czesko-niemieckich, Warszawa 2015, s. 145-158.

21 J. Barcz, Podstawy prawne stosunków Polski ze zjednoczonymi Niemcami, [w:] Polska-Niemcy 19452007. Od konfrontacji do współpracy..., s. 113-158. 
względem nie odbiegała znacząco od opracowań opisujących zjawisko rewizjonizmu zachodnioniemieckiego, powstałych w latach 60. i 70.XX w. ${ }^{22}$ Warto też zwrócić uwagę na sam tytuł wzmiankowanego opracowania, odnoszący się do polityki RFN względem „polskiej ludności rodzimej”.

Był to jeden z licznych przejawów niewiary polskiego społeczeństwa, polityków, ale i nauki, że procesy zmian tożsamościowych, jakie zachodziły na przestrzeni lat 1950-1989, spowodowały, iż część śląskiej ludności rodzimej zaczęła czuć się bardziej Niemcami niż Polakami. W tym miejscu nie można pominąć wpływu na te zmiany wzmiankowanej $\mathrm{w}$ innym artykule tego opracowania nieskuteczności zastosowanych w okresie powojennym (1945-1950) narzędzi polityki narodowościowej, na czele z procesem weryfikacji narodowościowej.

Wspomniano wcześniej, że wydane po wizycie H. Kohla Wspólne Oświadczenie nadało kierunek polsko-niemieckich rozmów. W niecały rok po jego wizycie rządy RP i RFN, zawierając traktat graniczny, rozwiązały problem graniczny, który komplikował wzajemne relacje przez poprzednie 41 lat. Co interesujące, po zawarciu pierwszego traktatu polsko-niemieckiego, $\mathrm{w}$ agendzie kolejnego etapu bilateralnych negocjacji, zagadnienie mniejszości niemieckiej w Polsce zajęło czołowe miejsce ${ }^{23}$. W rezultacie istotna część traktatu o dobrym sąsiedztwie i przyjaznej współpracy została dedykowana społeczności mniejszości niemieckiej w Polsce i Polonii w Niemczech ${ }^{24}$.

Co ważne, równolegle do toczących się rozmów bilateralnych, procesu zjednoczenia Niemiec i transformacji systemowej w Polsce następował proces stopniowego włączania się mniejszości niemieckiej w polskie życie publiczne, przy czym najbardziej było to widoczne w wymiarze politycznym ${ }^{25}$. Dlatego też refleksji na temat udziału mniejszości niemieckiej w polskim życiu publicznym po 1989 r. nie można

22 Por. A. Brożek, Losy Niemców w Polsce po roku 1944/45. Fikcja liczb zachodnioniemieckich a rzeczywisty bilans ludnościowy, Opole 1965; idem, Przesiedleńcy w Niemczech. Charakterystyka demograficzna, Katowice 1963; R. Buchała, Zachodnioniemieckie poglądy o tzw. „Recht auf die Heimat” (W zakresie psychologii i socjologii), Katowice 1964.

23 Uwagi i propozycje $w$ zwiqzku z VIII rundq rozmów pełnomocników szefów rzqdów PRL i RFN M. Pszona i H. Teltschika (14-16.09.1989), [w:] Polska wobec zjednoczenia Niemiec 1989-1991. Dokumenty dyplomatyczne, red. W. Borodziej, Warszawa 2006, s. 109.

24 Na przytoczenie w całości zasługuje tutaj ust. 1 w artykule 20 traktatu: „1. Członkowie mniejszości niemieckiej w Rzeczypospolitej Polskiej, to znaczy osoby posiadające polskie obywatelstwo, które są niemieckiego pochodzenia albo przyznają się do języka, kultury lub tradycji niemieckiej, a także osoby w Republice Federalnej Niemiec, posiadajace niemieckie obywatelstwo, które sa polskiego pochodzenia, albo przyznają się do języka, kultury lub tradycji polskiej, mają prawo, indywidualnie lub wespół z innymi członkami swej grupy, do swobodnego wyrażania, zachowania i rozwijania swej tożsamości etnicznej, kulturalnej, językowej i religijnej bez jakiejkolwiek próby asymilacji wbrew ich woli. Mają oni prawo do pełnego i skutecznego korzystania z praw człowieka i podstawowych wolności bez jakiejkolwiek dyskryminacji i w warunkach pełnej równości wobec prawa". Pełna treść dokumentu zob.: http:// www.traktaty.msz.gov.pl/fd.aspx?f=P0000006258.pdf (dostęp: 10 IX 2016 r.).

25 O bilansie realizacji traktatu w kontekście implementowania treści dokumentu na rzecz mniejszości niemieckiej za okres 1991-2011 zob. szerzej: A. Trzcielińska-Polus, Mniejszość niemiecka w Polsce. Implementacja art. art. 20-22 Traktatu o dobrym sqsiedztwie i przyjaznej współpracy, [w:] Przełom i wyzwanie. XX lat polsko-niemieckiego traktatu o dobrym sqsiedztwie i przyjaznej współpracy. 1991-2011, red. W.M. Góralski, Warszawa 2011, s. 370-392. 
prowadzić bez uwzględnienia czynników, które budowały ówczesny międzynarodowy, a zwłaszcza bilateralny (polsko-niemiecki) kontekst sytuacji, w jakiej znajdowało się polskie państwo i społeczeństwo. Czynniki te i ich wzajemne oddziaływanie na siebie były odpowiedzialne za ukierunkowanie rozwoju zarówno stosunków polsko-niemieckich na poziomie politycznym, jak i ruchu mniejszości niemieckiej. Stąd też zagadnienie obecności mniejszości niemieckiej w polskim życiu publicznym po 1989 r. nie może być rozpatrywane bez uwzględnienia dynamiki i treści polsko-niemieckiej współpracy. Także i dzisiaj mniejszość niemiecka stara się włączać w polsko-niemiecki dialog na poziomie bilateralnym. Strona mniejszościowa była bowiem uczestnikiem obrad polsko-niemieckiego „okrągłego stołu”, który stanowi forum dialogu bilateralnego utworzonego w 2010 r. przy okazji podsumowania realizacji polsko-niemieckiego traktatu dobrosąsiedzkiego z 1991 r. ${ }^{26}$

Dynamiczna budowa struktur organizacyjnych mniejszości niemieckiej, zainicjowana równolegle do procesu polskiej transformacji systemowej z jednej strony, a polsko-niemieckiego zbliżenia $\mathrm{z}$ drugiej, umacniała znaczenie społeczne i polityczne tej społeczności. Stosunkowo szybko na terenie gmin zamieszkiwanych przez opolskich Niemców powstawały niemieckie koła przyjaźni - Deutsche Freundschaftskreise - DFK. Dzisiaj jest ich 330 i są obecnie w niemal każdym sołectwie województwa opolskiego, na terenie którego zamieszkują przedstawiciele mniejszości niemieckiej. Koła DFK są bazą organizacyjną TSKN, którego struktura obejmuje również poziom gminny, powiatowy i wojewódzki.

Obowiązujący statut organizacji wśród celów działalności TSKN wspomina także o uczestnictwie w życiu społeczno-publicznym, w szczególności w formie udziału w referendach i wyborach parlamentarnych krajowych i europejskich oraz wyborach samorządowych wszystkich szczebli. W tym wymiarze mniejszość niemiecka od przeszło 25 lat jest aktywnym uczestnikiem opolskiego życia publicznego ${ }^{27}$, czynnie go współkształtując.

\section{Działalność polityczna mniejszości niemieckiej}

Wspomniana wcześniej akcja zbierania podpisów z 1989 r., która miała pokazać potencjał ludnościowy mniejszości niemieckiej na Śląsku, była pierwszym wyraźnym sygnałem, że społeczność ta w warunkach demokratyzującej się rzeczywistości społeczno-politycznej nie dopuści do tego, żeby jej obecność była nadal przemilczana. Szybko też ujawniła swoje ambicje i cele polityczne.

Wydarzeniem, które stało się pierwszym sprawdzianem umiejętności mobilizacji politycznej mniejszości, ale i które pokazało siłę elektoratu tej społeczności, były wybory uzupełniające do Senatu w lutym 1990 r. Przyczyną organizacji tych wyborów 
była śmierć Edmunda Jana Osmańczyka w październiku 1989 r., który został wybrany do Senatu z ramienia solidarnościowego Komitetu Obywatelskiego ${ }^{28}$.

Ze względu na fakt, że w wyborach wzięło udział czterech kandydatów, przewidywano, że do rozstrzygnięcia będą potrzebne dwie tury. Wydawało się również, że status wyborów uzupełniających nie zachęci wielu wyborców do skorzystania ze swojego czynnego prawa wyborczego. Nie było zatem zaskoczeniem, że w pierwszej turze wzięło udział 31,4\% uprawionych do głosowania. Jednakże wygrał ją lider coraz bardziej aktywnego środowiska mniejszości niemieckiej, Henryk Kroll, uzyskując prawie 85 tys. głosów, podczas gdy jego kontrkandydaci zdobyli niecałe 128 tys.

Wynik I tury odbił się dużym echem nie tylko w regionie, ale i w skali całego kraju, przyczynił się również do masowej mobilizacji wyborców po obu stronach. W rezultacie w II turze frekwencja wzrosła do poziomu 54,8\%. H. Kroll uzyskał w niej około 125,5 tys. głosów, a Dorota Simonides - aż 258 tys. Oznacza to, że w podziale na preferencje wyborcze - elektorat przedstawiciela mniejszości niemieckiej wzrósł o 47\%, a polski o ponad $100 \%{ }^{29}$. Dwa tygodnie poprzedzające II turę wyborów uzupełniających z lutego 1990 r. były okresem niezwykle emocjonalnej kampanii wyborczej, której narracja oparła się na kwestii zderzenia dwóch wyobrażeń o kształcie opolskiego społeczeństwa.

Rozgrywane w warunkach demokracji wybory były też okazją do ujawnienia się podziałów społecznych i politycznych regionalnej społeczności. Fakt, że zyskały one kontekst polsko-niemieckiej rywalizacji sprawił, że w raczkującym dopiero demokratycznym dyskursie politycznym dominowały emocje podszyte stereotypowym postrzeganiem ludności, która w wymiarze tożsamościowym była nadal ludnością pogranicza kulturowego. Po stronie społeczności większościowej pojawiało się wiele głosów mówiących o "farbowanej” tożsamości opolskich Niemców, wskazywano też na czynniki ekonomiczne, które zachęcały Ślązaków do opowiadania się za niemieckością i otwartego demonstrowania swojej odrębności. Po stronie mniejszościowej natomiast odżywały emocje związane z poczuciem zagrożenia ze strony polskiego państwa i społeczeństwa. Zderzenie tych dwóch odmiennych punktów widzenia sprzyjało zamykaniu się społeczności i rozbudzaniu postaw nacjonalistycznych, ksenofobicznych i wzajemnej wrogości.

Wcale też nierzadkie były obawy przed przyszłym kształtem społeczności województwa opolskiego, która w momencie wkraczania w rzeczywistość demokracji

28 Obszerniej o postaci E.J. Osmańczyka zob. np.: Edmund Jan Osmańczyk (1913-1989). Materiały sesji naukowej zorganizowanej w pierwsza rocznice śmierci (19 listopada 1990 r.), red. M. Masnyk, Opole 1993; Edmund Jan Osmańczyk. Dziennikarz - publicysta - parlamentarzysta we wspomnieniach bliskich i przyjaciół, red. M. Masnyk, S.S. Nicieja, Opole 2004. 
i pluralizmu poddawana była silnym tendencjom dezintegrującym ${ }^{30}$. Danuta Berlińska w badaniach zrealizowanych pod koniec lat 90 . XX w. wskazywała, że na początku tej dekady aż $1 / 4$ mieszkańców województwa prezentowała postawę ksenofobiczną. Rozbudzone wtedy nastroje nacjonalistyczne zaczęły słabnąć dopiero po kilku latach ${ }^{31}$.

Wyniki wyborów uzupełniających do Senatu były wstępem do zaplanowanych na maj 1990 r. pierwszych wolnych wyborów samorządowych. Młode TSKMN na Śląsku Opolskim (po 1993 r. TSKN) było patronem utworzenia wielu lokalnych komitetów wyborczych w opolskich gminach. W ten sposób mniejszość niemiecka do pierwszych wyborów samorządowych występowała jako jedna z czołowych sił politycznych. Wyniki wyborów zakończyły się dla polskich Niemców sukcesem. Komitety wyborcze TSKN wystartowały w 38 na 63 gminy województwa opolskiego, w większości z nich uzyskały większość w wybranych radach, a w 2 nawet wszystkie mandaty, w 25 - mogły samodzielnie kształtować politykę na szczeblu lokalnym ${ }^{32}$.

Ta szersza refleksja na temat wyborów z 1990 r. jest w kontekście rozważań na temat partycypacji mniejszości niemieckiej w polskim życiu publicznym o tyle ważna, ponieważ osiągnięte wówczas wyniki wyborcze, a także pokazane zdolności mobilizacyjne w zakresie uczestnictwa w akcie wyborczym, wyznaczyły na przyszłe lata kierunek działalności mniejszości niemieckiej. Ponadto aktywne włączenie się mniejszości w życie polityczne, współkształtowanie społeczeństwa obywatelskiego na poziomie lokalnym i regionalnym, uczyniły z mniejszości niemieckiej społeczność współodpowiedzialną za los i kierunek rozwoju województwa, jak i poszczególnych samorządów gminnych, wchodzących w jego skład.

W kontekście takiego ukierunkowania działalności mniejszości niemieckiej, w pierwszym okresie ich działalności było widocznych wiele pozytywów. Można nawet stwierdzić, że TSKN na Śląsku Opolskim może być uważane za równolatka

30 Wydarzenia na Śląsku Opolskim z uwagą śledziła także prasa niemiecka. W poczytnym i opiniotwórczym tygodniku „Die Zeit” w maju 1990 r. ukazał sie artykuł, w którym nakreślono problem zderzenia kultur i tożsamości, które wówczas obserwowano na Opolszczyźnie: „Skąd się biorą wszyscy ci Niemcy, którzy od kilku miesieccy organizuja się na Górnym Ślasku, i którzy wystawiaja nawet swoich kandydatów w wyborach do polskiego parlamentu i w majowych wyborach samorządowych? Niemcy z polskimi imionami i nazwiskami, mówiący praktycznie tylko po polsku, którzy jednak nie mogą się doczekać niemieckiej mszy, choć maja problem z jej zrozumieniem? Czy ludzie, którzy przez 45 lat wyrastali bez niemieckiego języka, niemieckiej literatury, bez kultury i historii są w ogóle Niemcami? «Farbowańcy», można usłyszeć z ust niektórych polskich sąsiadów, którzy pod koniec wojny zostali przesiedleni z utraconych polskich terenów wschodnich na «odzyskany» Śląsk. Przecież po wojnie przed komisjami weryfikacyjnymi przyznawali się dobrowolnie do polskości. Gdyby byli prawdziwymi Niemcami, to wyjechaliby najpóźniej w latach 70. Teraz kusi ich - jak mówią niektórzy - twarda waluta niemiecka. Ale tych rzekomych pseudo-Niemców, którzy zapisują się do Towarzystwa Społeczno-Kulturalnego Niemców na Śląsku Opolskim wcale nie ciągnie na «złoty» Zachód. Chcą pozostać tam, gdzie pracowali i gdzie spoczeli na wieki ich rodzice i dziadkowie. Tam, gdzie drzewa wiśni ciagle jeszcze ciagna sie wzdłuż dróg, a z Góry Świętej Anny otwiera się widok na dalekie równiny [...] Tu na Śląsku Opolskim jest ich dom. Lecz prowadzona przez ostatnie 45 lat polityka polonizacji sprawiła, że stali się obcy we własnej ojczyźnie”. Cyt. za: H. Hirsch, Obcy we własnej ojczyźnie. Niemcy na Górnym Ślasku: jeszcze trzyma ich „w domu”, ale jak długo?, [w:] Niemcy w Polsce. Artykuły z polskiej i niemieckiej prasy z lat 1989-2010, Gliwice-Opole 2010, s. 59.

31 D. Berlińska, Mniejszość niemiecka na Śląsku Opolskim w poszukiwaniu tożsamości, Opole 1999, s. 216. 
polskiej demokracji i przejaw pozytywnych zmian w polskim społeczeństwie po 1989 r., a również za organizację, która walnie przyczyniła się do budowy opolskiego społeczeństwa obywatelskiego. Jednakże nie należy zapominać, że mimo tej aktywności organizacyjnej, TSKN nie było w stanie przewyższyć poziomu mobilizacji politycznej z lutego 1990 r. Osiągnięty wówczas wynik wyborczy pozostał szczytem możliwości docelowego elektoratu mniejszości niemieckiej.

Na osiągnięte rezultaty działalności TSKN należy patrzeć także krytycznie, ponieważ liderom tego ruchu nie udało się odwrócić tradycyjnego - ale w warunkach demokracji dla niej samej niekorzystnego - powściągliwego uczestnictwa rodzimych Ślązaków w życiu publicznym. Aktywiści mniejszości niemieckiej i wyborcy TSKN są bowiem jedynie częścią tej społeczności, a osiągane w ostatnich wyborach poparcie wyborcze (w przeliczeniu na liczbę oddanych głosów na listy mniejszości niemieckiej) nie odzwierciedla rzeczywistego potencjału ludnościowego, a w dalszej konsekwencji - społeczno-politycznego tej grupy.

Województwo opolskie, a zwłaszcza gminy tradycyjnie zamieszkiwane przez ludność rodzimą, cechują się najniższym poziomem frekwencji wyborczej w Polsce. Ponadto położenie w pierwszym okresie działalności TSKN nacisku głównie na aspekt polityczny, przyczyniło się do tego, że organizacja ta nie była w stanie zachęcić do działalności przedstawicieli młodszych pokoleń. Utarło się bowiem społeczne przekonanie, że mniejszość poprzez swoją organizację funkcjonuje w województwie opolskim jako trzecia lub czwarta siła polityczna, choć jednocześnie jej liderzy, eksponując znaczenie tej organizacji w sferze społeczno-kulturalnej, przypominaja, że TSKN jest największą w regionie organizacją pozarządową ${ }^{33}$.

Wydaje się, że w pierwszych latach działalności najwięcej trudności sprawiało liderom mniejszości osiągnięcie równowagi między aktywnością i realizacją celów organizacji na gruncie politycznym a społeczno-kulturalnym i tożsamościowym przede wszystkim.

Oznacza to, że entuzjazm związany z możliwością zaktywizowania społeczności opolskich Niemców, pobudzony transformacją ustrojową, został zużyty dla politycznej strony działalności tej organizacji, ale właśnie ze szkodą dla jej społecznego, kulturalnego i tożsamościowego wymiaru. Na tym gruncie zrodziły się w późniejszych latach poważne problemy związane z zachęcaniem do działania na rzecz organizacji mniejszości niemieckiej przedstawicieli młodszych roczników.

Po wyborach samorządowych z maja 1990 r., które umiejscowiły mniejszość niemiecką na opolskiej scenie politycznej, kolejnym sprawdzianem poparcia i możliwości mobilizacji elektoratu były pierwsze wolne wybory parlamentarne do Sejmu I kadencji i Senatu II kadencji z 1991 r. Wybory te, organizowane w oparciu o zasady

33 W niniejszym artykule w sposób marginalny autor omawia kulturalno-oświatową i społeczną strone działalności TSKN. Warto jednak pamietać, że organizacja ta realizuje rocznie wiele inicjatyw i przedsięwzięć ukierunkowanych na promocję języka i kultury niemieckiej. Inicjatywy te skierowane są nie tylko do dzieci i młodzieży szkolnej, lecz także do seniorów. Szczegółowy opis poszczególnych inicjatyw zob.: http://skgd.pl/dzialalnosc-kulturalno-oswiatowa/dzialalnosc-oswiatowa-tskn/ i http://skgd. pl/dzialalnosc-polityczno-spoleczna/aktywnosc-spoleczna/animatorzy-osob-starszych/ (dostęp: 10 IX 2016 r.). 
większościowej ordynacji wyborczej (w celu ujawnienia zróżnicowania politycznego), zakończyły się sukcesem komitetu wyborczego TSKN.

Mniejszość zamieszkująca teren województwa opolskiego wprowadziła do parlamentu czterech posłów i jednego senatora. Sejmową reprezentację polskich Niemców poszerzyło kolejnych trzech przedstawicieli, którzy trafili do Sejmu z terenu województwa katowickiego. Za ten sukces wyborczy niewątpliwie był odpowiedzialny swoisty „efekt świeżości” organizacji mniejszości i fakt, że elektorat mniejszościowy nie dokonał jeszcze oceny działalności swoich liderów politycznych. Wynik z wyborów 1991 r., kiedy ordynacja wyborcza nie przewidywała progów wyborczych, nie został już powtórzony ${ }^{34}$.

$\mathrm{Z}$ biegiem lat siła elektoratu mniejszości niemieckiej $\mathrm{w}$ wyborach parlamentarnych stosunkowo się zmniejszała. Ciekawe obliczenia w tym zakresie przedstawiła D. Berlińska, która zauważyła, że w kolejnych wyborach parlamentarnych poparcie mniejszości systematycznie malało. Spadek następował nie tylko w wymiarze oddanych głosów, lecz także na poziomie odnotowanej frekwencji. Podczas gdy Henryk Kroll jeszcze w lutym 1990 r. uzyskał prawie 130 tys. głosów, to na listy mniejszości niemieckiej w 1991 r. oddało swój głos ponad 74 tys. osób, w 1993 r. około 61 tys., a w 1997 r. - 51 tys. ${ }^{35}$ Spadek poparcia widoczny był także w wyborach do Senatu - od 1997 r. mniejszość w izbie wyższej parlamentu nie ma swojego przedstawiciela. W rezultacie w Sejmie II kadencji mniejszość reprezentowało trzech posłów, w Sejmie III, IV i V - dwóch, a od 2007 r. jedynym posłem z ramienia mniejszości niemieckiej był Ryszard Galla. Ostatnim senatorem z ramienia TSKN był Gerhard Bartodziej, który zasiadał w Senacie III kadencji (1993-1997). Przywoływana autorka słusznie zauważyła, że oferta wyborcza organizacji mniejszości niemieckiej nie była na tyle atrakcyjna, by dla rodzimych mieszkańców Śląska TSKN było głównym wyborem politycznym. Zwracała też uwagę, że jeszcze w 1990 i 1991 r. liczebność tej społeczności została uszczuplona przez ostatni „rzut” emigracji do RFN ${ }^{36}$. W istocie, w samym tylko 1990 r. do Niemiec wyjechało aż 134 tys. osób ${ }^{37}$, co musiało mieć wpływ na siłę elektoratu mniejszości niemieckiej.

W ostatnich wyborach parlamentarnych z października $2015 \mathrm{r}$. TSKN uzyskało 27530 głosów poparcia, tj. 8,14\% w skali regionu ${ }^{38}$. W porównaniu z wynikiem wyborczym osiągniętym w lutym 1990 r., obecne poparcie TSKN, wyrażone w liczbie oddanych głosów, stanowi nieco ponad 20\% dawnego wyniku. Rezulat minionych

34 Imienna lista reprezentantów mniejszości, którzy zasiadali w polskim parlamencie po 1991 r., zob.: http://vdg.pl/pl/article/14-przedstawicielstwo-w-sejmie-historia (dostęp: 10 IX 2016 r.)

35 D. Berlińska, Mniejszość niemiecka..., s. 221.

36 Ibidem, s. 221-228.

37 A. Trzcielińska-Polus, „Wysiedleńcy” z Polski w Republice Federalnej Niemiec w latach 1980-1990, Opole 1997, s. 41.

38 Zob. strony internetowe Państwowej Komisji Wyborczej: http://parlament2015.pkw.gov.pl /349_Wyniki_Sejm/0/0/21 (dostęp: 10 IX 2016 r.). 
wyborów parlamentarnych pozwolił na zdobycie mandatu, lecz perspektywy jego poprawy są niewielkie. Stały i wierny elektorat mniejszości niemieckiej zmniejsza się, a elektorat potencjalny, czyli rodzimi mieszkańcy Śląska, wolą oddawać swoje głosy na partie ogólnopolskie, upatrując w tym większych szans na realizację swoich interesów politycznych. Taki mechanizm znajduje zastosowanie także w wypadku wyborów do Parlamentu Europejskiego. Organizacja tych wyborów, a zwłaszcza stosowany podział kraju na okręgi wyborcze, sprawia, że mniejszość niemiecka nie widzi szans na uzyskanie mandatu i tym samym nie tworzy samodzielnego komitetu wyborczego. Województwo opolskie w przypadku tego rodzaju wyborów wchodzi bowiem w skład dolnośląsko-opolskiego okręgu wyborczego, a stosowana zasada proporcjonalności prowadzi do tego, że szanse na uzyskanie mandatu mają jedynie silne ogólnopolskie komitety wyborcze. Jest to zarazem jedna z głównych przyczyn, wspomnianej już, dramatycznie niskiej frekwencji wyborczej podczas wyborów do PE.

Jednakże wybory parlamentarne nie są głównym celem zainteresowania politycznego TSKN. Rzeczywista siła i znaczenie polityczne tej organizacji w regionie uwidacznia się w jej obecności w strukturze samorządu terytorialnego. W poniższej tabeli (Tabela 1) zaprezentowano sumaryczny zestaw wyników, jakie osiągnęły komitety wyborcze TSKN w ostatnich wyborach samorządowych z 2014 r.

Tabela 1. Wyniki TSKN w wyborach samorządowych w 2014 r. w województwie opolskim.

\begin{tabular}{|c|c|c|c|}
\hline Wybierany organ & Nazwa komitetu & $\begin{array}{l}\text { Liczba zgłoszonych } \\
\text { kandydatów }\end{array}$ & $\begin{array}{l}\text { Liczba uzyskanych } \\
\text { mandatów }\end{array}$ \\
\hline $\begin{array}{c}\text { Sejmik Województwa } \\
\text { Opolskiego }\end{array}$ & \multirow{5}{*}{$\begin{array}{c}\text { Komitet Wyborczy } \\
\text { Towarzystwo Społeczno- } \\
\text {-Kulturalne Niemców na } \\
\text { Śląsku Opolskim }\end{array}$} & 46 & 7 \\
\hline Rady powiatu & & 266 & 45 \\
\hline $\begin{array}{c}\text { Rady miast powyżej } \\
100 \text { tys. mieszkańców } \\
\text { (Opole) }\end{array}$ & & 50 & 1 \\
\hline Rady gminy & & 450 & 259 \\
\hline $\begin{array}{l}\text { Wójtowie, } \\
\text { burmistrzowie, } \\
\text { prezydenci }\end{array}$ & & 28 & 24 \\
\hline \multicolumn{2}{|c|}{ Razem: } & 840 & 336 \\
\hline
\end{tabular}

Źródło: opracowanie własne na podstawie danych Państwowej Komisji Wyborczej dostępnych na stronach internetowych www.pkw.gov.pl (dostęp: 10 IX 2016 r.). 
Mimo iż od wielu lat poparcie dla komitetów mniejszości niemieckiej maleje, to pod względem liczby przedstawicieli $\mathrm{w}$ strukturach samorządu terytorialnego w województwie opolskim, TSKN zalicza się nadal do czołowych formacji politycznych w regionie. Nadal też w wielu gminach jest główną, a w zasadzie jedyną siłą polityczną. Wystarczy bowiem przytoczyć $w$ tym miejscu fakt, że w gminach Jemielnica i Walce, TSKN ma obecnie 14 na 15 mandatów ${ }^{39}$. Jednakże na takie przykłady gmin należy patrzeć $\mathrm{z}$ innej perspektywy. W wielu obwodach (sołectwach) udział w wyborach do rady gminy w sposób czynny zgłaszają od wielu lat te same osoby, często są jedynymi chętnymi ${ }^{40}$.

Oznacza to, że choć mniejszość jest tam dominującą siłą polityczną, to w wymiarze obywatelskim społeczność lokalna jest w dużej mierze wyalienowana i nie przejawia woli ani w czynnym, ani tym bardziej w biernym uczestnictwie w wyborach. W rezultacie gminy mniejszościowe w województwie opolskim to także gminy, w których odnotowuje się najniższą frekwencję $\mathrm{w} \mathrm{kraju}^{41}$. Analizując zagadnienie aktywności politycznej mniejszości niemieckiej, nie można również zapominać o tym, że w żadnej z gmin, gdzie w organach uchwałodawczych radni TSKN stanowią większość, udział osób narodowości niemieckiej nie przekracza 35\% ogółu mieszkańców ${ }^{42}$. Tym samym liczna reprezentacja TSKN $w$ radach gmin tych społeczności lokalnych nie odzwierciedla rzeczywistej liczebności mniejszości na ich terenie.

Funkcjonujące $w$ tym wymiarze sprzeczności - niski poziom partycypacji obywatelskiej z jednej strony, a dominacja TSKN w wymiarze aktywności politycznej $\mathrm{z}$ drugiej strony, tworzą pole do realizacji interdyscyplinarnych badań naukowych, których celem byłoby rozpoznanie źródeł tego dysonansu.

Warto w tym miejscu zwrócić uwagę również na fakt, że mniejszość niemiecka współuczestniczy w realizacji polityki na rzecz rozwoju regionu na poziomie sejmiku województwa opolskiego. Co ważne, w organie tym TSKN tworzy koalicje, które pozwalają na współrządzenie regionem od 1999 r. Od momentu utworzenia samorządu

39 Postępujący spadek poparcia, a tym samym znaczenia politycznego mniejszości widać także po stopniowym zmniejszaniu się liczby przedstawicieli mniejszości w radach i zarządach powiatów województwa opolskiego. Za przykład można tu podać zmiany na przestrzeni 2010 i 2014 r. Podczas gdy w latach 2010-2014 w czterech powiatach starostowie byli reprezentantami mniejszości, to od $2014 \mathrm{r}$. starostowie z ramienia TSKN piastują swoje funkcje w powiecie strzeleckim i opolskim. Zob. http://vdg. pl/pl/article/16-starosci-mniejszosci-niemieckiej (dostęp: 10 IX 2016 r.).

40 W sytuacji, kiedy w obwodzie wyborczym do wyborów zgłosił się tylko jeden kandydat, głosowanie jest dwuwariantowe. Wyborca na karcie do głosowania zaznacza obok nazwiska kandydata do rady gminy „tak” lub „nie”. Kandydat uzyskuje mandat wówczas, gdy liczba głosów na „tak” przekroczy 50\% przyp. aut.

41 Zob. wyniki wyborów samorządowych z 2014 r. na stronach Państwowej Komisji Wyborczej: http:// samorzad2014.pkw.gov.pl (dostęp: 10 IX 2016 r.).

42 Mniejszość niemiecka zamieszkuje w 50 z 71 gmin województwa opolskiego, w 20 liczebność tej społeczności przekracza 20\% ogółu mieszkańców: Strzeleczki 32,9\%, Biała 32,2\%, Reńska Wieś 32,0\%, Cisek 30,9\%, Lasowice Wielkie 29,5\%, Radłów 28,7\%, Zebowice 28,3\%, Prószków 26,2\%, Kolonowskie 26,2\%, Walce 26,0\%, Leśnica 25,7\%, Jemielnica 24,5\%, Tarnów Opolski 22,2\%, Murów 22,1\%, Popielów 21,6\%, Polska Cerekiew 21,5\%, Ujazd 21,5\%, Turawa 21,0\%, Głogówek 20,9\%. Dane na podstawie danych Głównego Urzędu Statystycznego udostepnionych na stronach internetowych serwisu mniejszości narodowych i etnicznych:http://mniejszosci.narodowe.mac.gov.pl/mne/mniejszosci/charakterystyka-mniejs/6480,Charakte rystyka-mniejszosci-narodowych-i-etnicznych-w-Polsce.html (dostęp: 10 IX 2016 r.). 
terytorialnego na poziomie województwa, mniejszość niemiecka ma zawsze swojego przedstawiciela w Zarządzie Województwa Opolskiego. Refleksja o znaczeniu politycznym mniejszości $w$ wojewódzkich organach samorządowych jest o tyle istotna, że pozwala na ocenę rzeczywistego poziomu poparcia i potencjału wyborczego elektoratu tej społeczności. Choć liczba reprezentantów mniejszości w sejmiku od 2006 r. jest podobna, to jednak liczba oddanych na listy TSKN głosów była w 2014 r. najniższa od 1998 r. (Tabela 2). To niepokojące dla mniejszości niemieckiej zjawisko może się w kolejnych latach pogłębić. Uszczuplenie poparcia politycznego ma dwojakie przyczyny - po pierwsze elektorat mniejszości kurczy się w sposób naturalny, po drugie TSKN traci głosy na rzecz innych formacji politycznych, które dają wyborcom wizję skuteczniejszej realizacji ich interesów.

Tabela 2. Poparcie dla komitetów mniejszości niemieckiej w wyborach do Sejmiku Województwa Opolskiego w latach 2006-2014.

\begin{tabular}{|c|c|c|c|}
\hline Rok & Liczba uzyskanych głosów & $\begin{array}{c}\text { Procent poparcia } \\
\text { w skali województwa }\end{array}$ & Liczba mandatów \\
\hline 2006 & 49131 & $17,30 \%$ & 7 \\
\hline 2010 & 53670 & $17,77 \%$ & 7 \\
\hline 2014 & 41889 & $14,76 \%$ & 6 \\
\hline
\end{tabular}

Źródło: opracowanie własne na podstawie danych Państwowej Komisji Wyborczej dostępnych na stronach internetowych www.pkw.gov.pl (dostęp: 10 IX 2016 r.).

Mniejszość niemiecka i jej przedstawiciele zasiadający w radach gmin, powiatów i sejmiku województwa opolskiego bądź szefujący gminom w roli wójtów lub burmistrzów mogą dwojako realizować interesy opolskich Niemców. Po pierwsze - są współodpowiedzialni za rozwój społeczności lokalnej i regionalnej, ale mogą także aktywnie korzystać - w sensie konsumować - z możliwości, jakie polskie państwo tworzy w wymiarze prawnym i finansowym dla mniejszości narodowych i etnicznych.

\section{Realizacja praw mniejszości narodowych i etnicznych $\mathbf{w}$ wymiarze opolskim ${ }^{43}$}

Mniejszość niemiecka zarówno swoją liczebnością, jak i faktem posiadania silnej struktury organizacyjnej ma sposobność pełnego wykorzystania możliwości, jakie daje polskie prawo w zakresie wsparcia mniejszości narodowych i etnicznych. 
Mniejszość niemiecka może korzystać z tych możliwości w wymiarze formalnym i finansowym. Wymiar finansowy polega na pozyskiwaniu dotacji i grantów pozwalających na realizację „zadań i inicjatyw umożliwiających rozwój, kształtowanie i podtrzymywanie poczucia odrębności mniejszości w dziedzinie kultury i edukacji, realizację projektów i działalność statutową organizacji mniejszości"44. Warto przypomnieć, że wsparcie finansowe mniejszości przybiera też kształt powiększonej subwencji oświatowej, która trafia do gmin organizujących nauczanie języka niemieckiego jako języka mniejszości narodowej. W ten sposób do większości opolskich gmin, bo nauka języka niemieckiego jako języka mniejszości organizowana jest w ponad pięćdziesięciu gminach regionu, w roku szkolnym 2014/2015 trafiło ponad $80 \mathrm{mln}$ zł dodatkowych środków finansowych ${ }^{45}$. Wielkość tej kwoty z roku na rok wzrasta, tak jak liczba uczniów uczęszczających na zajęcia języka niemieckiego jako języka mniejszości. W roku szkolnym 2015/2016 prawie 31 tys. dzieci i uczniów, uczęszczających do opolskich przedszkoli, szkół podstawowych, gimnazjalnych i ponadgimnazjalnych, brało udział w tego rodzaju zajęciach ${ }^{46}$. Oznacza to jednocześnie, że ponad $22 \%$ wszystkich dzieci i uczniów z terenu województwa korzysta $\mathrm{z}$ edukacji skierowanej dla mniejszości narodowych i etnicznych. W tym kontekście rodzi się wiele pytań, gdyż procentowy udział społeczności opolskich Niemców w opolskiej społeczności regionalnej jest mniejszy niż wynikałoby to ze statystyk Systemu Informacji Oświatowej. Zagadnienie to wymagałoby jednak pogłębionej refleksji, która przekroczyłaby ramy tego artykułu.

Opisany wyżej zakres działalności organizacji mniejszości narodowych i etnicznych (w tym kontekście niemieckiej), które mogą być wspierane przez państwo, wypływa wprost z art. 35 Konstytucji RP. W tym artykule uwypuklony jest także drugi wymiar wsparcia - prawny, z którego mniejszość niemiecka korzysta, współtworząc rejestry gmin:

a) na terenie których mogą być używane dodatkowe nazwy miejscowości w języku mniejszości (dwujęzyczne tablice),

b) na terenie których może być używany język mniejszości jako język pomocniczy.

Mniejszość niemiecka aktywnie korzysta z powyższych możliwości. Wystarczy wymienić, że 28 gmin województwa opolskiego (stan na 1 stycznia 2016 r.) jest wpisanych do rejestru gmin, na terenie których mogą funkcjonować dwujęzyczne tablice, a 22 - do rejestru gmin, w których w podstawowych kontaktach obywatela z gminą można używać języka niemieckiego.

44 Więcej zob. na stronach serwisu: http://mniejszosci.narodowe.mac.gov.pl/mne (dostęp: 10 IX 2016 r.).

45 Informacje udostępnione na stronach serwisu Ministerstwa Spraw Wewnętrznych i Administracji: http://mniejszosci.narodowe.mac.gov.pl/mne/komisja-wspolna/grupy-robocze/finasowanie-zadanoswia/9175,Prace-grupy-roboczej-Komisji-Wspolnej-Rzadu-i-Mniejszosci-Narodowych-i-Etnicznyc. html (dostęp: 10 IX 2016 r.).

46 Dane pochodzą z Systemu Informacji Oświatowej udostępnionych na stronie internetowej: https:// cie.men.gov.pl/index.php/dane-statystyczne/140.html (dostęp: 10 IX 2016 r.). 
Powyższe liczby mogą wskazywać, że efekty wykorzystywania możliwości wsparcia mniejszości narodowych, z jakich korzysta społeczność opolskich Niemców, można zaliczać do sukcesów udziału mniejszości niemieckiej w polskim życiu publicznym. Sukcesy te mają jednak częstokroć Janusowe oblicze. Bo oto, chociaż w 22 gminach województwa można używać języka niemieckiego w kontakcie $\mathrm{z}$ organami gminy, to $\mathrm{w}$ wielu z nich kontaktów tych nie ma albo są sporadyczne. Do mniejszości należą te gminy, w których język niemiecki jest aktywnie włączany w życie publiczne. Wydaje się, że dążenia do utworzenia z województwa opolskiego regionu, w którym polsko-niemiecka dwujęzyczność jest elementem rzeczywistości społeczno-kulturowej, jest niemożliwe. Chociaż instytucje mniejszości, wspierające edukację i obecność języka niemieckiego w przestrzeni publicznej, tj. Niemieckie Towarzystwo Oświatowe i Dom Współpracy Polsko-Niemieckiej ${ }^{47}$, realizują projekty i inicjatywy nakierowane na popularyzację używania języka niemieckiego w życiu codziennym, to jednak mimo wszystko język niemiecki nie jest językiem codzienności. Potencjał ludnościowy tej społeczności, jak również uwarunkowania historyczno-kulturowe przyczyniają się do tego, że zakorzenienie w województwie opolskim idei regionu dwujęzycznego będzie trudne. Dla mniejszości niemieckich niedoścignionym wzorem pod tym względem może pozostać społeczność regionu autonomicznego Trydent-Górna Adyga we Włoszech, w którym język niemiecki jest obok języka włoskiego drugim językiem urzędowym.

Ważnym aspektem uczestnictwa mniejszości niemieckiej w życiu publicznym jest ponadto jej udział, razem $z$ innymi uznanymi przez polskie prawo mniejszościami narodowymi i etnicznymi, w obradach Komisji Wspólnej Rządu i Mniejszości Narodowych i Etnicznych. Ciało to tworzone przez ustawę o mniejszościach stanowi forum dialogu między stroną rządową a mniejszościami. W jej składzie zasiada obecnie dwóch reprezentantów polskich Niemców ${ }^{48}$.

$* * *$

Mniejszość niemiecka jest ważnym segmentem opolskiego społeczeństwa, tworzy zarazem podstawę zróżnicowania etnicznego i kulturowego regionu. Jej obecność może być uznawana z jednej strony jako ubogacenie województwa, z drugiej zaś za dowód wielobarwnej i skomplikowanej historii Śląska. Fakt, że uczestniczy aktywnie w opolskim życiu publicznym od początku przemian demokratycznych w Polsce, czyni zeń ważnego współtwórcę regionalnego społeczeństwa obywatelskiego. Mniejszość niemiecka jest aktywnym uczestnikiem życia publicznego w wielu sferach. Wykorzystując możliwości uczestnictwa mniejszości narodowych w rywalizacji politycznej w polskim systemie politycznym, bierze czynny udział w wyborach

47 Mowa m.in. o projekcie „Bilingua - łatwiej z niemieckim!”. Więcej o projekcie zob.: http://haus.pl/ aktualnosci-1061.html (dostęp: 10 IX 2016 r.). 
samorządowych i parlamentarnych, wystawiając w nich własny komitet wyborczy pn. Towarzystwo Społeczno-Kulturalne Niemców na Śląsku Opolskim.

Towarzystwo to jest zarazem największą pod względem liczby członków, jak również najbardziej rozbudowaną strukturalnie organizacją pozarządową w województwie. Dzięki temu może współkształtować życie społeczno-kulturalne Opolszczyzny.

Wieloaspektowa działalność i aktywność mniejszości niemieckiej, obejmująca oprócz sfery politycznej (wybory) i społeczno-kulturalnej także uczestnictwo w dialogu między rządem RP a mniejszościami narodowymi i etnicznymi w formule Komisji Wspólnej oraz korzystanie ze zróżnicowanych form wsparcia tych grup, tworzonych przez polskie prawo, czyni zeń jednego z najważniejszych aktorów opolskiego dyskursu i życia publicznego. Wydaje się, że obecnie nadrzędnym celem działalności organizacji mniejszości niemieckiej powinno stać się stworzenie funkcjonalnego i atrakcyjnego dla młodszego pokolenia forum kształtowania i promocji postaw tożsamościowych. Z punktu widzenia perspektyw rozwoju tej społeczności jest to szczególnie istotne, ponieważ negatywne zjawiska demograficzne, dotykające grupę mniejszości mocniej niż resztę opolskiego społeczeństwa, mogą w przyszłości silnie osłabiać ludnościowy - a w dalszej konsekwencji społeczno-kulturalny i - obszernie już opisany - polityczny potencjał tej grupy. 


\section{Bibliografia}

14 listopada 1989, wspólne oświadczenie Mazowiecki-Kohl, [w:] Polska-Niemcy 1945-2007. Od konfrontacji do wspótpracy i partnerstwa w Europie. Studia i dokumenty, red. W.M. Góralski, Warszawa 2007, s. 355-361

20 lat TSKN na Ślqqsku Opolskim, red. R. Urban, Z. Donath-Kasiura, Opole 2009

Barcz J., Podstawy prawne stosunków Polski ze zjednoczonymi Niemcami, [w:] Polska-Niemcy 19452007. Od konfrontacji do wspótpracy i partnerstwa w Europie. Studia i dokumenty, red. W.M. Góralski, Warszawa 2007, s. 113-158

Berlińska D., Mniejszość niemiecka na Ślqsku Opolskim w poszukiwaniu tożsamości, Opole 1999

Brożek A., Losy Niemców w Polsce po roku 1944/45. Fikcja liczb zachodnioniemieckich a rzeczywisty bilans ludnościowy, Opole 1965

Brożek A., Przesiedleńcy w Niemczech. Charakterystyka demograficzna, Katowice 1963

Buchała R., Zachodnioniemieckie poglady o tzw. „Recht auf die Heimat” (W zakresie psychologii i socjologii), Katowice 1964

Cygański M., Polityka Republiki Federalnej Niemiec wobec polskiej ludności rodzimej na Ślq̨sku w latach 1949-1990/91, Opole 1991

Edmund Jan Osmańczyk (1913-1989). Materiały sesji naukowej zorganizowanej w pierwszq rocznicę śmierci (19 listopada 1990 r.), red. M. Masnyk, Opole 1993

Edmund Jan Osmańczyk. Dziennikarz - publicysta - parlamentarzysta we wspomnieniach bliskich i przyjaciól, red. M. Masnyk, S.S. Nicieja, Opole 2004

Hirsch H., Obcy we własnej ojczyźnie. Niemcy na Górnym Ślq̨sku: jeszcze trzyma ich „w domu”, ale jak długo?, [w:] Niemcy w Polsce. Artykuły z polskiej i niemieckiej prasy z lat 1989-2010, Gliwice-Opole 2010, s. 59-62

Lis M., Mniejszość niemiecka na Ślq̨sku Opolskim 1989-2014. Z bagażem przeszłości w realiach współczesności, Opole 2015

Mazurkiewicz M., Regionalne uwarunkowania polityki polskiej wobec mniejszości narodowych i etnicznych na przykładzie województwa opolskiego, „Studia Śląskie”, t. LXXVII (2016), s. 53-74

Mazurkiewicz M., Spór o pamięć. Polityczne następstwa powojennych wysiedleń Niemców w pozimnowojennych relacjach polsko-niemieckich i czesko-niemieckich, Warszawa 2015

Sawczuk J., Od status quo do planu Kohla. Geneza zjednoczenia Niemiec w świetle opublikowanych dokumentów Urzędu Kanclerskiego (1989 r.), Opole 2005

Skubiszewski K., Wysiedlenie Niemców po II wojnie światowej, Warszawa 1968

Tokarz K., Mniejszość niemiecka w Polsce w prasie RFN w latach 1989-1997, [w:] Węzłowe problemy Niemiec XX-XXI wieku, red. K. Fiedor, M.S. Wolański, Wrocław 2002, s. 153-168

Trzcielińska-Polus A., Mniejszość niemiecka w Polsce. Implementacja art. art. 20-22 Traktatu o dobrym sqsiedztwie i przyjaznej współpracy, [w:] Przełom i wyzwanie. XX lat polsko-niemieckiego traktatu o dobrym sq̨siedztwie i przyjaznej współpracy. 1991-2011, red. W.M. Góralski, Warszawa 2011, s. 370-392

Trzcielińska-Polus A., „Wysiedleńcy” z Polski w Republice Federalnej Niemiec w latach 1980-1990, Opole 1997

Uwagi i propozycje w zwiqzzk z VIII rundq rozmów pełnomocników szefów rzq̨ów PRL i RFN, M. Pszona i H. Teltschika (14-16.09.1989), [w:] Polska wobec zjednoczenia Niemiec 1989-1991. Dokumenty dyplomatyczne, red. W. Borodziej, Warszawa 2006, s. 109-112 


\section{Partycypacja mniejszości niemieckiej w polskim życiu publicznym po 1989 r. - przypadek Ślqska Opolskiego}

Streszczenie: Artykuł jest próbą politologicznego spojrzenia na zagadnienie partycypacji mniejszości niemieckiej w polskim życiu publicznym w okresie pozimnowojennym. Autor uczestnictwo społeczności polskich Niemców analizuje na przykładzie udziału organizacji mniejszości niemieckiej w wyborach parlamentarnych i samorządowych oraz wykorzystywaniu możliwości wsparcia, jakie mniejszościom narodowym i etnicznym daje polskie prawo. Autor podzielił problematykę na trzy elementy. W pierwszym przybliża proces uzyskiwania podmiotowości przez mniejszość niemiecką po $1989 \mathrm{r}$. i włączania się tej społeczności w życie polityczne na poziomie lokalnym, regionalnym oraz ogólnopolskim - poprzez uczestnictwo w wyborach parlamentarnych. W kolejnej części autor przybliża w sposób syntetyczny bilans uczestnictwa organizacji mniejszości niemieckiej w wyborach samorządowych i parlamentarnych na przestrzeni ćwierćwiecza 1990-2015. W części ostatniej artykułu autor przybliża najistotniejsze rezultaty realizacji praw na rzecz mniejszości narodowych i etnicznych, będące udziałem działalności mniejszości niemieckiej w województwie opolskim.

\section{Participation in public life in Poland post 1989 by the German minority community - the case of Opolian Silesia}

Abstract: This article is an attempt at an analysis from a political science standpoint of the issue of participation by the German minority community in public life in Poland in the post Cold War period. The author analyses the participation of the Polish German community in the light of both the contribution made by the German minority organisation in parliamentary and local government elections and their use of the potential support guaranteed to them under Polish law as a national and ethnic minority. The article presents this discussion in three parts. The first deals with the process of the acquisition of societal recognition by the German minority after 1989 and the entry of this community into political life at local, regional and national levels - through participation in parliamentary elections. In the next part, the author discusses in a synthetic manner the overall participation of the German minority organisation in local and parliamentary elections during the quarter century between 1990 and 2015. In the final part of the article, the author focuses on the most crucial results of the enactment of laws related to national and ethnic minorities resulting from the activity of the German minority in the Opole voivodeship.

Słowa kluczowe: mniejszość niemiecka, Śląsk Opolski, wybory parlamentarne, wybory samorządowe, prawo na rzecz mniejszości narodowych i etnicznych

Key words: German minority, Opolian Silesia, parliamentary elections, local elections, law related to national and ethnic minorities 